\title{
Education Consumption: New Model for Russia and China
}

\author{
Natalya Zavyalova \\ Linguistics department \\ Ural Federal University named after the first President of Russia Boris Yeltsin \\ Ekaterinburg, Russian Federation \\ N.A.Zavialova@urfu.ru
}

\begin{abstract}
Urban family consumption in China includes such important issues as children's education. Interestingly, an education consumption model in Chinese families includes such expensive and inspiring features as studying abroad. However, it is necessary to point out that expensive European and North American schools and universities are still beyond the reach of many Chinese families. Driven by the crave for a better future for their children, more and more mid-level income Chinese families choose Russia as an overseas studying option for their children. Several of the most exciting questions raised in the paper are as follows. How is it possible for Russian universities to offer better studying conditions for Chinese students without big money supply from official educational authorities? Should Russian universities change their educational culture to better suit Chinese demands? How is it possible to observe a fragile balance between Russian national educational culture and learning conditions expected by Chinese students abroad?
\end{abstract}

Keywords - consumption, education, China, Russian Federation, learning

\section{INTRODUCTION}

For many rich Chinese families' education consumption has an added value of "right emotions received after proper investment". As Xiaoshan Lin put it, "family investment in children's education exhibits dual characteristics of instrumental rationality and emotional expression" [1]. It is critical to remember this idea and use it for the benefit.

The focal point of the paper is the case practiced by the author with Chinese and Russian students at the classes of introduction to Russian culture. The classes are held at the Department of linguistics of Ural Federal University named after the first President of Russia Boris Yeltsin. The educational program's title is "Russian Studies in Real Russia". The research questions are as follows. Do all the students from various countries have the same primary understanding of culture? If no, is it possible to make the educational program of Russian studies more effective proceeding from the differences in culture visions and the ways of communicating cultures? How is it possible to apply the elements of simple design projects to classroom routines in order to communicate culture and culture differences? The paper describes an experimental case study which is formative and conducive for success strategies in educational markets of today and tomorrow
It is a common knowledge that culture is ubiquitous today. The concept of culture is fundamental to international marketing, advertising, show business and politics. Of much importance is the notion of culture for educational programs. Russian educational institutions are penetrating international markets and apply much effort to become more competitive in international instructional competition. They target international students who would like to learn more about Russian culture. The Peoples' Republic of China - a historically traditional big friend of Russia with a common communist past - is a Russian neighbor country whose people have always been very interested in Russian life, markets and, recently, in education. "The total number of students studying in China and Russia is growing every year and is striving for around 100 thousand people" [2]. Students from China very often get a relatively good intermediate level command of Russian at home and they are eager to advance their knowledge of Russian with native speakers in Russian natural environment. However, it is important for Russian universities to understand that their educational programs require a careful adaptation for the needs of Chinese students.

The central research question is as follows. What is the correct adaptive strategy for Russian educational products to better suit Chinese students' needs? The understanding of this question is fundamental to a more advanced position of Russian universities at international educational markets. On top of that, we are convinced that the concept of a flexible educational strategy is central to the successful present and future of Russia as a friend of China because education targets young generations who are major decision makers today and tomorrow [3].

We started our description from the idea that culture is ubiquitous today. The second ubiquitous issue, which is to be found everywhere, is design. The sphere of design covers the areas of human-beings' life starting from early childhood to people's final days. It is the primary concern of the paper to blend culture and design together to make Russian educational programs more competitive. While discussing the approaches to primary understanding of cultures, providing brief cultural definitions we distributed among the students cut-paper models of blank T-shirts (Fig.1). Their classroom design task was to decorate the T-shirt model for cultural symposium participants as if they were professional designers. In their design they had to reflect their understanding of culture in the 
However, the central source of cultural data was an images, proceeding from the idea that they were making designs for professional cultural experts taking part in the toplevel professional event.

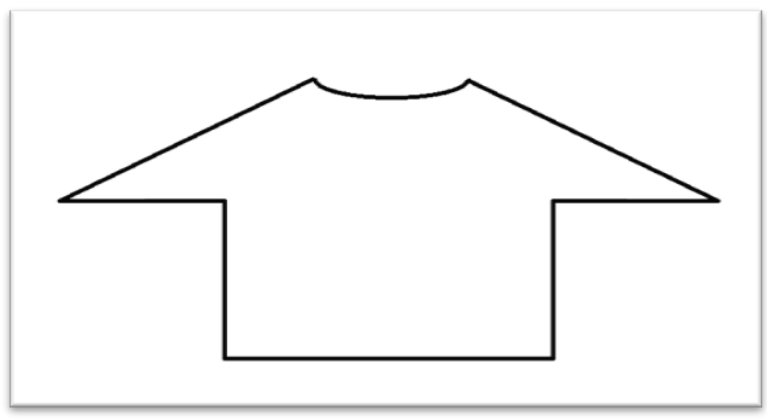

Fig 1. A T-shirt model for the international forum of culture experts

Right cultural approaches and design are common conditions which have a considerable impact on market knishes for Russian educational programs.

Design is a major area not for a passive consuming of things and products but also for an active participation of individuals in creative activities which unveil their inner world. Consequently, the introduction of design activities to classroom routines may be an effective approach which appeals to the core of human nature. Design can play an important role in addressing the issue of knowledge application rather than passive learning strategies which develop apathy among students and kill their intrinsic interest in the subject [4].

Culture and design are increasingly important areas of modern life in the global world which is also a global market place. There is a growing body of literature which recognizes the importance of cultural reflection in design concepts and products [5]. There is much evidence that culture plays a crucial role in the selection of colours, patterns and models. Central to the entire concept of design is the notion that culture is the key determinant which makes one product attractive to consumers in one country and disgusting to people in another country [6]. The same laws are applicable to the sphere of education. Investigating the interplay of culture and design is our continuing concern which is a key research area of the paper.

\section{METHODS AND MATERIALS}

In our research we use the methods of active watching and group discussion which enable to synchronously reflect on the ideas of several people. The advantage of the mixture of methods is the idea that they provide fresh visions for deep reflections. Another advantage of our case conditions is that there were students of both nationalities, Russian and Chinese, studying in the same group on the same premises. The students were asked to work in an individual self-mode regime without interacting with one another. experimental case. The composition of the experimental group included 4 undergraduates from China and 9 undergraduates from Russia. The procedure of the experiment included several stages which are as follows.

Stage 1. It is necessary to imagine that you were instructed to create T-shirts for a cultural symposium. What do you mean by culture?

Stage 2. Using your own understanding of culture, create a T-shirt design. Reflect your vision of culture in the form of symbols, put these symbols on the model, justify the presented concept. The maximum number of characters is 15 . You can use words in both Russian and English.

Task execution time: 25 minutes. At the end of this time period, students need to put down all pens and pencils and begin presenting the created T-shirt, describing the symbols depicted, the concepts of the symbols represented, their own examples.

During the proposed case, the students and the teacher used active and passive observation methods. During the passive phase the participants completed the task and at the level of classroom routines they were only allowed to express requests to transfer pencils or pens of the desired color, and during the active phase they listened to presentations and fixed basic ideas of symbols of culture and their concepts in protocols.

Case materials. All students were given paper white mock-ups, cut-outs of thick cardboard t-shirt models made according to the design model (Figure 1). Also, all undergraduates received protocols for fixing observations (Table I). It took students 20 minutes to fill in the table.

TABLE I. MODEL OF THE OBSERVATION PROTOCOL DURING THE PRESENTATION OF THE CONCEPT OF CULTURAL SYMBOLS DEPICTED ON A TSHIRT MODEL FOR THE INTERNATIONAL SYMPOSIUM OF CULTURE EXPERTS

\begin{tabular}{|c|c|c|}
\hline $\begin{array}{l}\text { Student's first and } \\
\text { family name }\end{array}$ & Culture symbol & $\begin{array}{c}\text { The interpretation of } \\
\text { the symbol }\end{array}$ \\
\hline \multirow[t]{5}{*}{ Student1. } & Symbol 1. & \\
\hline & Symbol 2. & \\
\hline & Symbol 3. & \\
\hline & Symbol 4. & \\
\hline & Symbol 5. & \\
\hline \multirow[t]{5}{*}{ Student 2.} & Symbol 1. & \\
\hline & Symbol 2. & \\
\hline & Symbol 3. & \\
\hline & Symbol 4. & \\
\hline & Symbol 5. & \\
\hline \multicolumn{3}{|l|}{ Student $3 \ldots$} \\
\hline Student $13 \ldots$ & & \\
\hline
\end{tabular}


years when everything in China needed building and rebuilding, a large number of Soviet specialists gave all their wisdom and strength to help China build an industrial base from scratch [7].

Over the past seventy years, relations between the two states and peoples have experienced both periods of boom and bust. Today, looking back at the joint path traveled, both Russians and Chinese are aware of its historical significance. The main lesson of the past 70 years is that good neighborliness, friendship and cooperation correspond to the national interests of the two countries, while hostility and rivalry directly contradict them. The past three decades have been marked by a number of epoch-making events: the full normalization of bilateral relations, the establishment of a mechanism for regular meetings at the level of heads of state and government, the signing of the "Agreement on the GoodNeighborliness, Friendship and Cooperation" [8], the establishment of strategic partnership relations, the creation of the SCO and the subsequent development of ties within this organization, the final solving the border issue, holding a number of thematic cross-years. The past three decades have been marked by a number of epoch-making events: the full normalization of bilateral relations, the establishment of a mechanism for regular meetings at the level of heads of state and government, the signing of the "Agreement on the Neighborhood, Friendship and Cooperation" [9], the establishment of strategic partnership relations, the creation of the SCO and the subsequent development of ties within this organization, the final solving the border issue, holding a number of thematic cross-years. Neither Russia nor China have such an extensive system of contacts with any other country in the world. Following the results of 2018, bilateral trade turnover exceeded a record high of $\$ 100$ billion.

Strengthening ties between the regions of the PRC and Russia plays an increasingly important role. The geography of interregional contacts is expanding, and new mechanisms for cross-border cooperation are appearing. The experience of creating a mechanism of interregional interaction in the VolgaYangtze format, covering the regions of the Volga Federal District and the upper, middle reaches of the Yangtze River, was successful. A fruitful discussion is underway of new mechanisms for interregional cooperation with the participation of regions of the two countries that are geographically remote from each other. Cooperation is developing dynamically in the field of security, the fight against terrorism, and also within the framework of the Chinese program "One Belt, One Road” [10].

In late August 2019, the exhibition entitled "Ceremonies of the Russian Imperial Court" from the collection of the Moscow Kremlin Museums opened in the Gugun Imperial Palace. This exposition is a reciprocal exhibition within the framework of a cooperation project between Russian and Chinese museums. In March-May 2019, the exhibition "Treasures of the Imperial Palace of Gugun" was held in Moscow [11].

For 6 years, Chairman Xi Jinping paid a visit to Russia 8 times, held 30 meetings with President V.V. Putin in bilateral and multilateral formats. The heads of China and Russia 
Cultural comfort of Chinese students in Russia is an visited partner states to attend important ceremonies and international conferences. Xi Jinping handed to V.V. Putin the highest state award of the PRC - the Order of Friendship. V.V. Putin awarded Xi Jinping the highest state order of the Holy Apostle Andrew the First-Called.

All these facts stress the importance of successful interaction between the two countries. There is much evidence that education plays a decisive role in this process of interaction. It bridges the gap between the past and the future of our countries [12].

Intensification of interaction within the framework of the community of countries BRICS contributes to the influx of Chinese students into Russian high schools [13]. The methods of teaching Russian as a foreign language are generally based on deep immersion in the Russian national culture. However, for Chinese students, any cultural environment must be deeply rooted into the native base [14]. Consequently, the way to improve the learning environment for Chinese students in Russia should be focused on possible application of Chinese symbols, as well. We find it reasonable to use Chinese imagery and symbols to offer comparative strategies describing Russian culture and the Russian language. For the students who are far from their native environment it is always a pleasant mental journey to native lands which makes a learning process more comfortable and comprehensive [15].

\section{CONCLUSION}

The current study found that Russian students create $\mathrm{T}$ shirts which reflect their outward understanding of different cultures. They see the symposium as a perfect opportunity to discuss and celebrate cultural differences, to learn more about foreign cultures, even try them, if an opportunity presents itself. Their designs are often centered around people of different nationalities holding hands together, saying "hello" in various languages, foreign flags. Interestingly, Chinese students in their designs resort to native culture images (bamboos, tea, red lanterns, pandas and Beijing Olympic Games symbols namely) which testify to the fact that Chinese students are inwardly oriented while doing culture studies.

One more important finding is that while communicating Russian culture to Chinese students it might be effective to offer comparisons of Russian culture with Chinese culture stemming from the fact that Chinese students expect elements of their native culture everywhere. Such comparisons might make the educational process simpler and more transparent. We strongly believe in this model of education consumption based on a careful mixture of Chinese and Russian symbols. Another important finding of this research is an attempt to blend art-design elements and discussion on culture understanding and acquisition. important issue for future research. Further research should be undertaken in the areas of inspiring for Chinese students' research topics and methodologies. Unlike many popular opinions, we insist on the fact that abundant financial support from Russian educational authorities is not the only issue for successful reception of Chinese students in Russia. Further studies, which take these variables into account, will need to be undertaken.

\section{References}

[1] X. Lin, "Purchasing hope": the consumption of children's education in urban China," The Journal of Chinese Sociology, vol. 6 (8), pp.24-34, 2019

[2] N. Zavyalova, "Dataset for an analysis of communicative aspects of finance," Data in Brief, vol. 11, pp. 197-203, 2017.

[3] N. Zavyalova N., E.M. Akhmetshin, "BRICS soft power promotion: Dataset for media preference and use pattern among the Russian audience who follow the development of BRICS," Data in Brief, vol.16, pp. 939-946, 2018.

[4] Muratshina, K., \& Ivanova, A. "Foreign labour migrants in China opportunities and challenges," Mezhdunarodnye Protsessy, vol. 15(4), pp. 174-185, 2017.

[5] N.P. Tsepeleva, "Dialogue as a form of social construction in everyday life," European Journal of Science and Theology, vol. 14(4), pp. 131141, 2018.

[6] M.N. Dudin, E.E. Frolova, N.A. Lubents, V.D. Sekerin, S.V. Bank, and A.E. Gorohova, "Methodology of analysis and assessment of risks of the operation and development of industrial enterprises," Quality - Access to Success", vol. 17(153), pp. 53-59, 2016

[7] T.Y. Bystrova, L.V. Tokarskaia, "Psychlogical feasibility of design for children with autism spectrum disorders," Lifestyle and Health, vol. 1, pp. 223-235, 2018

[8] W.F. Tilden, "American cultural traits," Journal of Psychohistory, vol. 40(3), pp. 193-221, 2013.

[9] H.P. Peng, M.C. Chang, "The foundations of Chinese attitudes towards advocating luxury spending," European Journal of the History of Economic Thought, vol.19(5), pp. 691-708, 2012.

[10] N. Rohmetra, P. Arora, "International careers across cultures: A choice or rejection? International Journal of Diversity in Organizations," Communities and Nations, vol. 11(1), pp. 57-76, 2012.

[11] J. Zhou, A study on the structure of Chinese lexicon (hanyu cihu jiegoulun). Shanghai: Shanghai Dictionary Press (in Chinese), 2004, pp: 230 .

[12] Hui Zhang, Yiming Yang, Jiexin Gu and Feng Ji, "ERP correlates of compositionality in Chinese idiom comprehension," Journal of Neurolinguistics, vol. 26: 89-112, pp. 90, 2013.

[13] H. Daly, "A further critique of growth economics," Ecological Economies, vol. 88, pp. 20-24, 2013.

[14] Takeshi Hamamura, Liman Man Wai Li, "Discerning Cultural Identification from a Thinly Sliced Behavioral Sample", Personality and Social Psychology Bulletin, vol. 38(12), pp. 1697-1706, 2012.

[15] D. Stephenson, S. Worthington, and R. Russell-Bennett. "The financial services cultural orientation matrix," Australasian Marketing Journal, vol. 21(1), pp.1-9, 2013 